\title{
A review of the human retina with emphasis on nerve fibre layer and macula thicknesses
}

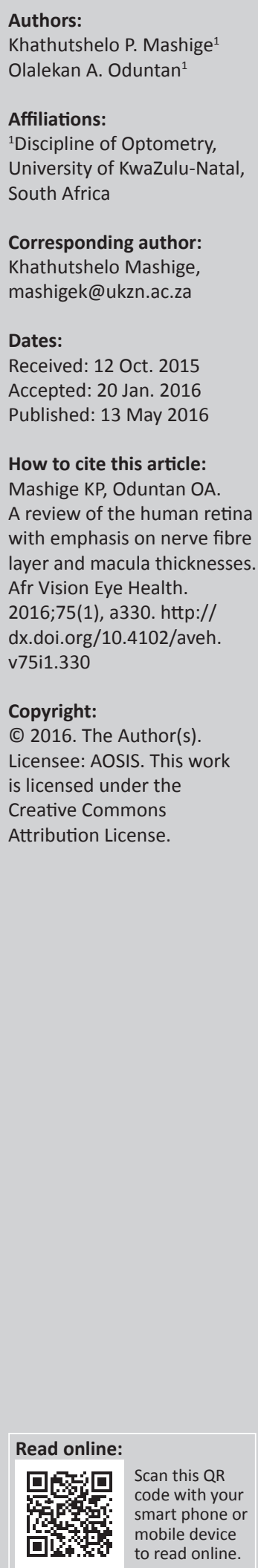

\begin{abstract}
The retina is the innermost neural layer of the eye, and is the site of transformation of light energy into a neural signal. Knowledge and assessment of the human retinal structural parameters are important for the appropriate diagnosis and management of various ocular diseases. For instance, potentially blinding eye diseases, such as glaucoma and age-related macular degeneration, cause structural changes in the retina. Clinical evidence with ocular coherence tomography also suggests that eyes with glaucoma lose retinal nerve fibre layer and ganglion cells axons before loss of visual function. These losses appear as a visible change in the optic nerve head and can be seen before visual field abnormalities are noticed by the patient. This review discusses certain aspects (anatomical structures, structural changes with eye diseases, and assessment methods) involving the human retina, their clinical importance, and factors that may influence them. The content of this article will be useful to optometrists and ophthalmologists who assess these parameters in normal patients as well as in those with eye conditions such as glaucoma.
\end{abstract}

\section{Introduction}

The retina is a light-sensitive tissue lining the inner surface of the eye and is bounded internally by the vitreous body and is externally connected to Bruch's membrane of the choroid. ${ }^{1}$ The retina includes the macula which is used for optimal vision and colour perception because it has multiple ganglion cell layers. ${ }^{2}$ At the centre of the macula is the fovea, a thin zone of retina composed exclusively of cones. The optic disc appears as an oval white area of approximately $3 \mathrm{~mm}^{2}$ $(2 \times 1.5 \mathrm{~mm}$ across $)$ and the optic cup is a central depression in the disc, penetrated by the central retinal artery and vein. ${ }^{3}$ Clinically, the assessment of the colour of the disc, configuration and depth of the disc of the physiologic cup, and appearance of the rim tissue and disc borders are important in glaucoma diagnosis and management. ${ }^{1,4}$ In papilledema, there is oedema of the optic disc because of an increase in intracranial pressure and this can be clinically observed as swelling of the optic disc in ophthalmoscopy. ${ }^{1,4}$

Retinal thickness differs from one area to the other, being approximately $0.56 \mathrm{~mm}$ near the optic disc, $0.1 \mathrm{~mm}$ at the ora serrata, $0.09 \mathrm{~mm}$ at the fovea, and $0.35 \mathrm{~mm}$ in the macula region. ${ }^{1}$ The retina is composed of pigment epithelial cells, photoreceptor cells, retinal support cells, and nerve cells that are organised into simple but distinct layers. Traditionally, the '10-layered' arrangement is used to describe the layers of the retina. From closest to farthest from the vitreous body (i.e. from closest to the front exterior of the head towards the interior and back of the head), the layers are: The inner limiting membrane or internal limiting membrane, nerve fibre layer, ganglion cell layer, inner plexiform layer, inner nuclear layer, outer plexiform layer, outer nuclear layer, external limiting membrane, photoreceptor cell layer, and retinal pigment epithelium (RPE). ${ }^{1}$

The retinal cells (photoreceptor, bipolar, and ganglion cells) are responsible for interpreting visual information from the environment in the brain. ${ }^{1,4}$ Photons of light are transformed into neural signals by the process of transduction. This process can be simplified into four stages: photoreception, transmission to bipolar cells, transmission to ganglion cells, and transmission along the optic nerve. ${ }^{5}$ Neuroglial cells in the retina, including Muller cells, microglial cells, and astrocytes provide structural support, and play a role in the neural tissue reaction to injury or infection. ${ }^{1,3,5}$

Considering the importance of retinal structural parameters in the diagnosis and management of ocular diseases; each layer and its clinical significance, common assessment methods and values, as well as factors influencing each are reviewed herein. 


\section{The inner limiting membrane or internal limiting membrane}

This layer forms the basement membrane at the interface between the vitreous and the retina, and forms the footplates of Muller cells. ${ }^{1,5}$ The membrane is $2.5 \mu \mathrm{m}$ thick and is present over the macula and anteriorly, and it is continuous with the internal limiting membrane of the ciliary body. ${ }^{1,5}$ In ophthalmoscopy, reflections from the internal limiting membrane can be seen as retinal sheen that appears glistening in younger individuals and is less evident in older persons. ${ }^{1}$

\section{Nerve fibre layer}

The nerve fibre layer (NFL) is the innermost layer of the fundus and consists of axons of the ganglion cells en route to the central nervous system. ${ }^{1}$ The NFL is thickest near the porous opticus (the portion of the optic nerve seen in the fundus with the ophthalmoscope), and is formed by the converging of all the retinal ganglion cell axons as they enter the optic nerve. ${ }^{1}$ The optic disc is usually observed for certain changes as a guide in determining the degree of nerve damage in eye conditions. For example, in glaucoma, the loss of axons in the optic nerve head is seen as a generalised enlargement of the optic nerve head cup with thinning of the neuro-retinal rim. ${ }^{1}$ An important grouping of fibres called the papillomacula bundle, which carries the information that determines visual acuity, radiate from the macula area to the optic disc. ${ }^{1,3}$ Therefore, lack of function of the NFL will cause loss of visual acuity or scotomas, as commonly seen in glaucoma patients. ${ }^{1,4}$ The retinal vasculature including the superficial capillary network is located in this layer, and the processes of Muller cells, which surround the vessels and nerve fibres are common in the NFL. ${ }^{5}$ Haemorrhages that are located in the NFL cause the blood to pool with a characteristic appearance (flame-shaped haemorrhages) because of the arrangement of the nerve fibres. ${ }^{1,4}$ These haemorrhages are common in diabetic, hypertensive, and other retinopathies. ${ }^{1}$

NFL thickness has been reported to be a reliable early marker for glaucoma risk and can predict the development of subsequent glaucomatous visual field loss. ${ }^{6}$ Similarly, proper diagnosis of ophthalmic diseases involving the NFL requires a substantive knowledge of its expected thickness and normal limits. ${ }^{7}$ The thickness has been found to be reduced in ocular diseases such as optic neuritis, glaucoma, and Alzheimer's disease, ${ }^{8}$ as well as in patients with sickle-cell haemoglobinopathy with focal macula thinning. ${ }^{9}$ However, other investigators did not find a reduction in NFL thickness in Alzheimer's disease. ${ }^{10}$ The reasons for these contradictions could be because of various factors such as the variability in ages, gender, ethnicities, and techniques used. Diagnostic tools such as scanning laser polarimeter (GDx; Carl Zeiss Meditec, Dublin, CA), Heidelberg retina tomographer, and scanning laser ophthalmoscope are suitable for quantitatively assessing the NFL thickness, except the NFL thickness in the macula area. ${ }^{11}$ Ocular coherence tomography (OCT) provides non-contact and non-invasive NFL thickness measurements and has become an essential clinical measure for objective glaucoma assessment. ${ }^{12}$ Several authors have reported NFL thickness in normal children and adults as well as those with ocular anomalies. Table 1 shows important results from such studies in different groups based upon ethnicity and age.

TABLE 1: Study characteristics and mean thickness of the retinal nerve fibre layer in different ethnic populations. All studies included both males and females.

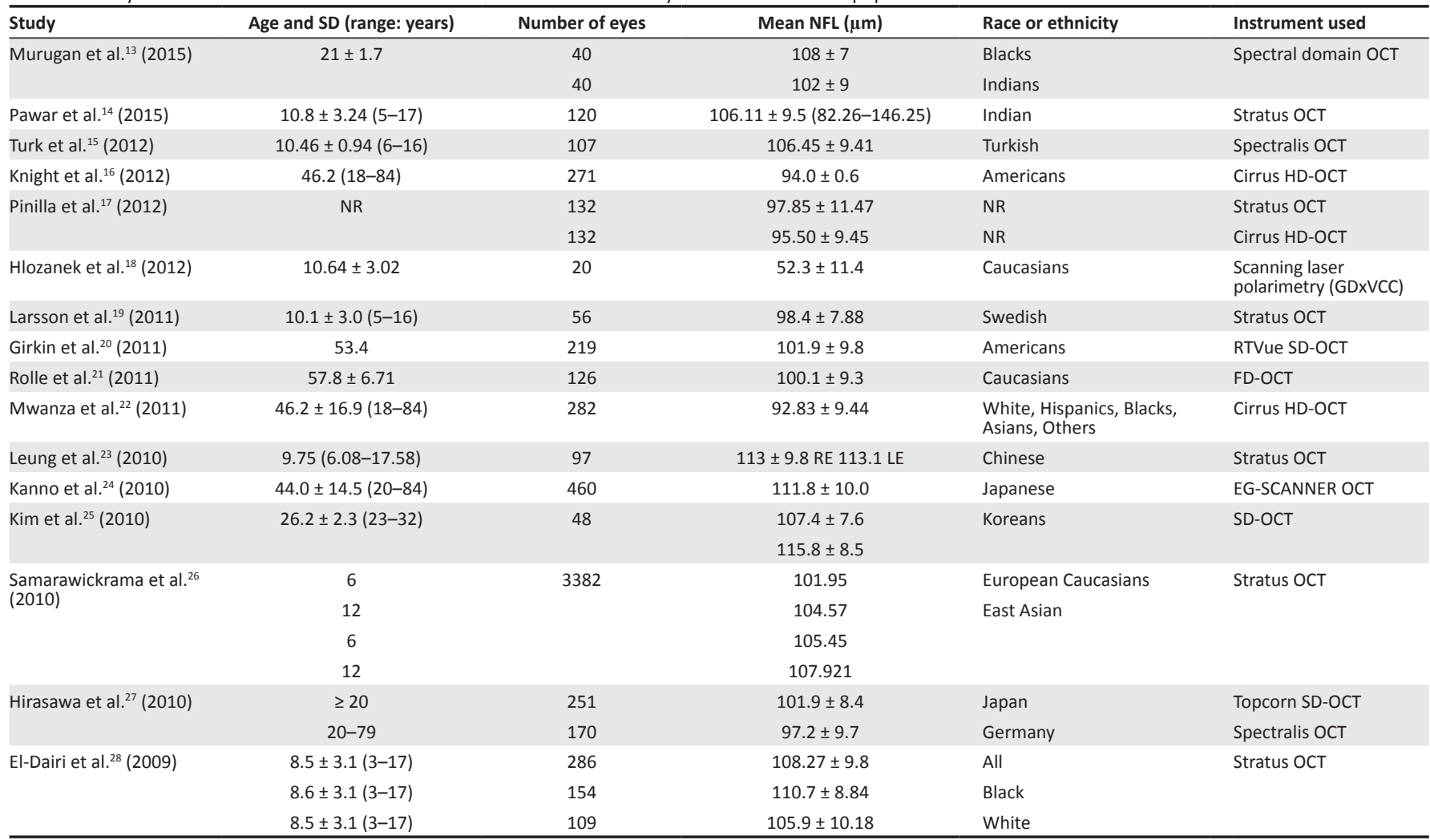


TABLE 1 (Continues...): Study characteristics and mean thickness of the retinal nerve fibre layer in different ethnic populations. All studies included both males and females.

\begin{tabular}{|c|c|c|c|c|c|}
\hline Study & Age and SD (range: years) & Number of eyes & Mean NFL $(\mu \mathrm{m})$ & Race or ethnicity & Instrument used \\
\hline Lu et al. ${ }^{29}$ (2008) & $56 \pm 9(40-76)$ & 89 & $96.3 \pm 9.9(72.7-124.3)$ & Caucasians & Stratus OCT \\
\hline Gupta et al..$^{30}(2007)$ & 6-13 & 18 & $100 \pm 2.64$ & NR & NR \\
\hline \multirow[t]{4}{*}{ Parikh et al. ${ }^{31}$ (2007) } & $11.1 \pm 3.9(5-20)$ & 59 & $100.15 \pm 10.8$ & Asian Indian & Stratus OCT \\
\hline & $24.7 \pm 3.6(20-35)$ & 49 & $98.76 \pm 12.7$ & & \\
\hline & $41.65 \pm 4.88(35-50)$ & 34 & $97.17 \pm 10$ & & \\
\hline & $55.58 \pm 4.25(50-75)$ & 45 & $92.28 \pm 9.56$ & & \\
\hline \multirow[t]{5}{*}{ Budenz et al. ${ }^{32}$ (2007) } & All & 206 & $98.1 \pm 10.9$ (96.7-99.7) & White & Stratus OCT \\
\hline & & 80 & $103.7 \pm 11.6(101.2-106.3)$ & Hispanic & \\
\hline & & 27 & $101.1 \pm 14(95.8-106.4)$ & African-American & \\
\hline & & 11 & $105.8 \pm 9.2(100.3-111.2)$ & Asian & \\
\hline & & 3 & $107.7 \pm 9.9(96.5-118.9)$ & Asian Indian & \\
\hline Salchow et al..$^{33}$ (2006) & $9.7 \pm 2.7(4-17)$ & 92 & $107 \pm 11.1$ & $\begin{array}{l}\text { Hispanic, African-American, } \\
\text { Caucasian }\end{array}$ & Stratus OCT \\
\hline Huynh et al. ${ }^{34}$ (2006) & $6.7 \pm 0.4(6-7)$ & 909 & $102.7(101-103.6)$ & White & Stratus OCT \\
\hline Repka et al..$^{35}$ (2006) & $9.2 \pm 1.5(7-12)$ & 37 & 109.6 & White, black, hispanic, latino & Stratus OCT \\
\hline Leung et al..$^{36}(2006)$ & $50.5 \pm 14.2$ & 42 & $106.44 \pm 11.15$ & Chinese & Stratus OCT \\
\hline Ahn et al. ${ }^{37}(2005)$ & $12.6 \pm 2.1(9-18)$ & 72 & $105.53 \pm 10.33$ & Koreans & Stratus OCT \\
\hline \multirow[t]{2}{*}{ Racette et al. ${ }^{38}$ (2005) } & $47.13 \pm 8.11$ & 42 & $114.86 \pm 15.14$ & Black and & \multirow{2}{*}{$\begin{array}{l}\text { Confocal scanning laser } \\
\text { ophthalmoscopy }\end{array}$} \\
\hline & $49.18 \pm 9.23$ & 34 & $108.50 \pm 17.17$ & White & \\
\hline $\begin{array}{l}\text { Mrugacz and Bakunowicz- } \\
\text { Lazarczyk }^{39}(2005)\end{array}$ & 10-18 & 26 & $95 \pm 26.3$ & Polish & ОСТ 2000 \\
\hline Bowd et al..$^{40}(2002)$ & $63.4 \pm 10.0(23-80.8)$ & 155 & $85.8(80.2-91.7)$ & Caucasians & ОСт 2000 \\
\hline $\begin{array}{l}\text { Poinoosawmy et al. }{ }^{41} \\
\text { (1997) }\end{array}$ & $43.9 \pm 20.9(5-90)$ & 150 & $78.2 \pm 10.6(55.4-105.3)$ & $\begin{array}{l}\text { White, Afro-Caribbean, } \\
\text { Asian Chinese }\end{array}$ & $\begin{array}{l}\text { Scanning laser } \\
\text { polarimetry }\end{array}$ \\
\hline
\end{tabular}

Note: Please see the full reference list of the article, Mashige KP, Oduntan OA. A review of the human retina with emphasis on nerve fibre layer and macula thicknesses. Afr Vision Eye Health. 2016;75 (1), a330. http://dx.doi.org/10.4102/aveh.v75i1.330, for more information.

In all studies the ocular status was normal except for Hlozanek et al., ${ }^{18}$ Rolle et al., ${ }^{21}$ Lu et al., ${ }^{29}$ Mrugacz and Bakunowicz-Lazarczyk ${ }^{39}$ where eyes were glaucomatous and Repka et al., ${ }^{35}$ where eyes had amblyopia.

$\mathrm{NFL}$, nerve fibre layer; NR, not reported; OCT, optical coherence tomography; SD, standard deviation.

\section{Ganglion cell layer}

This layer consists of ganglion cells and displaced amacrine cells, Muller cell bodies and astroglial cells. ${ }^{42}$ Ganglion cells are separated from each other by glial processes of Muller cells and are generally a single cell thick except near the macula, where they are several strata (about 8-10 cells thick) and the temporal side of the optic disc (where it is 2 cells thick). ${ }^{42}$ Current measures of visual function in glaucoma as based on conventional techniques such as the appearance of the optic disc, NFL, and standard achromatic perimetry, are relatively insensitive because research has shown that $25 \%$ $35 \%$ of retinal ganglion cells may be lost before an abnormality appears on standard achromatic perimetry. ${ }^{43}$ Therefore, modern technologies such as OCT which provide an in vivo cross-sectional images of ocular structures should be used.

\section{Inner plexiform layer}

Commonly referred to as the inner synaptic layer, this layer consists of cell processes and synapses of bipolar cells, amacrine cells, interplexiform cells, and ganglion cells. ${ }^{1}$ This layer also contains synapses between the bipolar cell axons and the dendrites of the ganglion and amacrine cells. ${ }^{1,3}$ This layer is responsible for initiating the processing of motion detection, changes in brightness, and recognition of contrast and hue. ${ }^{1,3}$

\section{Inner nuclear layer}

The inner nuclear layer consists of nuclei and cells bodies of bipolar cells, horizontal cells, interplexiform cells, and amacrine, as well as the nuclei of the Muller's cells and sometimes displaced ganglion cells. ${ }^{44}$ The main function of this layer is to receive input from the inner plexiform layer and project it to the outer plexiform layer. ${ }^{44}$ Haemorrhages in the inner nuclear layer appear rounded and often are called dot and blot haemorrhages. ${ }^{44}$

\section{Outer plexiform layer}

Also known as the outer synaptic layer, the outer plexiform layer has synaptic connections between photoreceptor cells, bipolar neurons, and horizontal cells. ${ }^{1}$ The projections of rods and cones end in the rod spherules and cone pedicles, respectively. ${ }^{3}$ These pedicles make synapses with dendrites of midget bipolar cells in the Fibres of Henle in the macula region. ${ }^{45}$ It is thought to be a membrane, known as middle limiting membrane, which demarcates the extent of the retinal vasculature. ${ }^{45}$ The middle limiting membrane may prevent the spread of retinal exudates and haemorrhages into the outer retinal layers. ${ }^{45}$

\section{Outer nuclear layer}

This layer contains the nuclei and cell bodies of the photoreceptor cells (rods and cones) and varies in width, being thickest in the fovea where it contains about 10 layers of cone nuclei. ${ }^{46}$ The outer nuclear layer is relatively thicker on the nasal edge of the disc (where it is 8-9 cells thick) compared to the 4 rows thick at the temporal edge. ${ }^{46}$ 


\section{External limiting membrane}

The external (outer) limiting membrane is not a true membrane and is composed of adherent junctions between Muller's cells and photoreceptors separating the inner segment portions of the photoreceptors from their cell nuclei. ${ }^{42}$ The adherent junctions can act to restrict the passage of large molecules, thus creating a metabolic barrier. ${ }^{42}$

\section{Photoreceptor layer}

This layer contains the inner and outer segments of photoreceptors (rods and cones). The rods are about $2 \mu \mathrm{m}$ thick and average of $50 \mu \mathrm{m}$ in length, possessing a roughly cylindrical outer segment. Cones are shorter and thicker, $3 \mu \mathrm{m}-5 \mu \mathrm{m}$ thick $\times 40 \mu \mathrm{m}$ long; their outer segment is conical in shape. ${ }^{42,45}$ Cones, which are active in well-lit illumination and perceive colour, are concentrated in the macula, and particularly in the fovea. ${ }^{42,45}$ Rods, which are more active in dim illumination, perceive light intensity but not colour, and are concentrated at the periphery of the retina. ${ }^{42,45}$ In certain eye conditions, the photoreceptors may be affected. For example, in retinitis pigmentosa, an autosomal dominant retinal dystrophy, the photoreceptors undergo apoptosis. ${ }^{1}$ The rod photoreceptors remain functional only in the far periphery and cones remain functional in the fovea, causing a ring-like scotoma visual field defect. ${ }^{1}$

\section{Retinal pigment epithelium}

The RPE sits immediately on Bruch's membrane and consists of a single layer of hexagonal cells, which are more densely pigmented in the macula area. ${ }^{42,45}$ The RPE are supportive cells and have macrophage function with little cell division occurring in the layer. ${ }^{47}$ The cells also contain melanosomes and pigment granules which differ in density in various parts of the retina. ${ }^{42,45}$ This gives the fundus a mottled appearance when viewed with the ophthalmoscope. ${ }^{1}$ Gap junctions are present between the cells and this allows for electric coupling, providing a low-resistance pathway for the passage of ions and metabolites. ${ }^{47}$ It is estimated that there are approximately 4-6 million RPE cells, and each cell interacts with 30-40 million photoreceptors. ${ }^{47}$ However, there are no intercellular junctions between these cells. The interface between the RPE and the photoreceptor layer is a common location of separation in a retinal detachment and an argon laser is often used to photocoagulate the border of a detachment, producing a scar tissue. ${ }^{47}$

This layer may be affected in certain eye diseases; for example, degeneration of the RPE and lipofuscin-like deposits (yellow and fleck-shaped) accumulation occurs in the macula area in Stargardt's disease, a hereditary autosomal recessive disorder that results in vision loss at an early age. ${ }^{1}$ Changes in the photoreceptors cause vision loss and by age 50 years, $50 \%$ of patients affected have a reduction of visual acuity of $6 / 60$ or worse. ${ }^{1}$ Another rare autosomal dominant disorder that presents in childhood as a yellow or orange egg yolk-like elevated lesion in the macula, called Best's disease or vitelliform macula dystrophy, results in deposits between the RPE and neural retina. ${ }^{1}$ In retinitis pigmentosa, there is a progressive loss of RPE and as the RPE degenerates, pigment migrates into the sensory retina, and accumulates around the blood vessels in a characteristic bone-spicule pattern. ${ }^{1}$ These bone-like spicules can be seen with an ophthalmoscope.

\section{Macula}

The macula region contains more than $50 \%$ of all the retinal ganglion cells and assessing ganglion cell changes in this region may be useful for diagnosing glaucoma. ${ }^{48}$ Recent evidence suggests that early glaucomatous damage involves the macula and can be missed and/or underestimated with standard visual field tests such as the 24-2 visual field test. ${ }^{49}$ Macula parameters can be measured with the OCT, and abnormal fluid accumulation within the retina and a concomitant increase in macula thickness usually result from the breakdown of the blood-retinal barrier, as seen in people with diabetic retinopathy, retinal vein occlusion, uveitis, and other ocular disorders. ${ }^{1}$ In ocular pathological conditions such as macula oedema, the normal orientation of the photoreceptors is altered causing visual distortions known as metamorphopsia, which can be elicited with an Amsler grid. ${ }^{1}$ The thickness of normal macula ranges according to the nine regions corresponding to the Early Treatment Diabetic Retinopathy Study (ETDRS), which include a central 1-mm disc, representing the foveal area, and the inner and outer rings of $3 \mathrm{~mm}$ and $6 \mathrm{~mm}$, respectively. ${ }^{50}$ The inner and outer rings are divided into four quadrants: superior, nasal, inferior, and temporal. ${ }^{50}$ Table 2 provides a summary of macula thickness profiles reported for healthy eyes.

\section{Factors influencing human retinal structural parameters}

Factors such as age, sex, race and ethnicity, axial length, and refractive error influence the retinal parameters. These factors are briefly reviewed below.

\footnotetext{
Age

Changes associated with ageing can be clinically observable in various retinal parameters. For example, an increase in the thickness of the internal limiting membrane because of increasing age dims the foveal reflex on ophthalmoscopy. ${ }^{59}$ Budenz et al. $^{32}$ found that thinner NFL thickness was associated with older age and the authors reported that for every decade of higher age, the mean NFL was thinner by approximately $2.0 \mu \mathrm{m}(95 \% \mathrm{CI}, 1.2-2.8)$. It has been reported that the human NFL loses about 2500 axons per year before age 50 and 7500 per year after 50 years of age. ${ }^{60}$ This agerelated change in NFL thickness should:

be taken into consideration when interpreting the lower limits of the normal range for diagnosis. For instance, an NFL thickness of $80 \mu \mathrm{m}$ may be normal for a 70 -year-old but would be abnormally low for the average 40-year-old. ${ }^{32}$
} 
TABLE 2: Previous studies of macula thickness values in different populations based on age and ethnicity.

\begin{tabular}{|c|c|c|c|c|c|c|c|c|}
\hline \multirow[t]{2}{*}{ Study } & \multirow{2}{*}{$\begin{array}{l}\text { Age and SD } \\
\text { (years) }\end{array}$} & \multicolumn{2}{|c|}{ Gender and mean thickness } & \multirow{2}{*}{$\begin{array}{c}\text { Number of } \\
\text { eyes }\end{array}$} & \multirow[t]{2}{*}{ ETDRS region } & \multicolumn{2}{|c|}{ Ethnicity and mean thickness } & \multirow[t]{2}{*}{ OCT version } \\
\hline & & Male & Female & & & Caucasian & African-American & \\
\hline $\begin{array}{l}\text { Wagner-Schuman } \\
\text { et al. } .^{50}(2011)\end{array}$ & $27.8 \pm 9$ & $\begin{array}{c}264.5 \pm 22.8 \\
316.2 \pm 16.4 \\
328.2 \pm 15.6 \\
331.4 \pm 18 \\
326.8 \pm 17.5 \\
265.5 \pm 15 \\
281 \pm 15.7 \\
301.6 \pm 14.9 \\
273.9 \pm 14.2\end{array}$ & $\begin{array}{l}253 \pm 19.3 \\
323 \pm 14.9 \\
322 \pm 13.9 \\
308 \pm 12.7 \\
318 \pm 13.6 \\
298 \pm 12.7 \\
279 \pm 13.3 \\
258.1 \pm 11 \\
268 \pm 11.6\end{array}$ & 90 & $\begin{array}{l}\text { Central } 1 \mathrm{~mm} \\
\text { Temporal inner macula } \\
\text { Superior inner macula } \\
\text { Nasal inner macula } \\
\text { Inferior inner macula } \\
\text { Temporal outer macula } \\
\text { Superior outer macula } \\
\text { Nasal outer macula } \\
\text { Inferior outer macula }\end{array}$ & $\begin{array}{c}266 \pm 18.2 \\
314 \pm 15.4 \\
326 \pm 15.5 \\
329 \pm 17.1 \\
323 \pm 16.8 \\
261 \pm 13.5 \\
279 \pm 14.1 \\
299 \pm 15 \\
271 \pm 13.1\end{array}$ & $\begin{array}{l}245.2 \pm 21.9 \\
323.4 \pm 16.4 \\
324.7 \pm 14.2 \\
310.1 \pm 14.6 \\
320.6 \pm 15.2 \\
300.9 \pm 11.5 \\
282.5 \pm 15.2 \\
263.8 \pm 14.0 \\
270.6 \pm 14.0\end{array}$ & Spectralis \\
\hline Liu et al..$^{51}(2011)$ & $57.7 \pm 15.1$ & $\begin{array}{c}283.5 \pm 14.6 \\
10.1 \pm 0.6 \\
322.8 \pm 18.3 \\
327.4 \pm 18 \\
324.2 \pm 18.9 \\
325 \pm 16.7 \\
282.8 \pm 22.6 \\
279.8 \pm 15.8 \\
282 \pm 22.5 \\
271.7 \pm 16.7\end{array}$ & $\begin{array}{c}278.7 \pm 14 \\
10 \pm 0.6 \\
314 \pm 17.8 \\
319 \pm 16.3 \\
316 \pm 15.5 \\
316 \pm 17.2 \\
274.6 \pm 28 \\
277 \pm 15.5 \\
278 \pm 21.8 \\
268 \pm 16.8\end{array}$ & 192 & $\begin{array}{l}\text { Macula thickness } \\
\text { Macula volume } \\
\text { Temporal inner macula } \\
\text { Superior inner macula } \\
\text { Nasal inner macula } \\
\text { Inferior inner macula } \\
\text { Temporal outer macula } \\
\text { Superior outer macula } \\
\text { Nasal outer macula } \\
\text { Inferior outer macula }\end{array}$ & - & - & Cirrus \\
\hline $\begin{array}{l}\text { Wexler et al. }{ }^{52} \\
(2010)\end{array}$ & $42.4 \pm 11.8$ & $\begin{array}{l}N=29 \\
180 \\
219 \\
281 \\
279 \\
N=16 \\
179 \\
211 \\
274 \\
272\end{array}$ & $\begin{array}{c}N=27 \\
173 \\
206 \\
266 \\
272 \\
N=35 \\
179 \\
211 \\
269 \\
273\end{array}$ & - & $\begin{array}{l}\text { Younger group } \\
\text { Mean minimal foveola } \\
\text { Mean foveal } \\
\text { Mean central } \\
\text { Mean temporal } \\
\text { Older group } \\
\text { Mean minimal foveola } \\
\text { Mean foveal } \\
\text { Mean central } \\
\text { Mean temporal }\end{array}$ & Norwegians & - & Stratus \\
\hline Sull et al..$^{53}(2010)$ & $36.1 \pm 15.9$ & $\begin{array}{l}208 \pm 14 \\
266 \pm 16 \\
234 \pm 16\end{array}$ & $\begin{array}{l}201 \pm 19 \\
258 \pm 17 \\
226 \pm 18\end{array}$ & 40 & $\begin{array}{l}\text { Cent subfield (Stratus) } \\
\text { Cent subfield (Cirrus) } \\
\text { Cent subfield (Topcon) }\end{array}$ & - & - & Cirrus \\
\hline $\begin{array}{l}\text { Kashani et al. }{ }^{54} \\
(2010)\end{array}$ & $49 \pm 12$ & $\begin{array}{c}163 \pm 3.0 \\
201.8 \pm 2.7 \\
263.1 \pm 1.9 \\
278.5 \pm 1.8 \\
278.4 \pm 1.9 \\
274.2 \pm 2.1 \\
226.5 \pm 1.8 \\
244.5 \pm 2.0 \\
261.5 \pm 2.2 \\
232.7 \pm 2.0\end{array}$ & $\begin{array}{c}154.7 \pm 2.5 \\
186.9 \pm 2.6 \\
250.9 \pm 1.8 \\
265.8 \pm 2.1 \\
263 \pm 2.1 \\
261.2 \pm 2 \\
215.4 \pm 1.7 \\
236.1 \pm 2 \\
251.2 \pm 1.9 \\
223.7 \pm 2.3\end{array}$ & 126 & $\begin{array}{l}\text { Central point foveal } \\
\text { Mean foveal } \\
\text { Temp inner macula } \\
\text { Superior inner macula } \\
\text { Nasal inner macula } \\
\text { Inferior inner macula } \\
\text { Temporal outer macula } \\
\text { Superior outer macula } \\
\text { Nasal outer macula } \\
\text { Inferior outer macula }\end{array}$ & $\begin{array}{l}164.1 \pm 2.8 \\
200.2 \pm 2.7 \\
257.1 \pm 2.4 \\
272.3 \pm 2.6 \\
271.9 \pm 2.8 \\
268.8 \pm 2.7 \\
218.6 \pm 2.1 \\
238.7 \pm 2.4 \\
256.3 \pm 2.6 \\
230 \pm 2.5\end{array}$ & $\begin{array}{c}147.2 \pm 3.6 \\
181 \pm 3.7 \\
251.5 \pm 2.5 \\
264.6 \pm 2.8 \\
262.7 \pm 2.8 \\
261.7 \pm 2.8 \\
217.8 \pm 2.7 \\
236.5 \pm 3.0 \\
251.9 \pm 2.8 \\
225.5 \pm 2.8\end{array}$ & Stratus \\
\hline $\begin{array}{l}\text { Song et al. }{ }^{55} \\
\text { (2010) }\end{array}$ & $55.6 \pm 16.4$ & $\begin{array}{c}259.4 \pm 23 \\
309.5 \pm 17 \\
320.7 \pm 18.2 \\
323.5 \pm 18.4 \\
315 \pm 19.6 \\
261.6 \pm 16 \\
274.3 \pm 15.7 \\
293.3 \pm 17.3 \\
266.7 \pm 14.9\end{array}$ & $\begin{array}{l}247.9 \pm 24 \\
298 \pm 31.7 \\
313.9 \pm 21 \\
316.6 \pm 18 \\
308 \pm 20.2 \\
253.7 \pm 24 \\
275.3 \pm 14 \\
290.3 \pm 18 \\
261.9 \pm 17\end{array}$ & 198 & $\begin{array}{l}\text { Central subfield } \\
\text { Temporal inner macula } \\
\text { Superior inner macula } \\
\text { Nasal inner macula } \\
\text { Inferior inner macula } \\
\text { Temporal outer macula } \\
\text { Superior outer macula } \\
\text { Nasal outer macula } \\
\text { Inferior outer macula }\end{array}$ & - & - & Cirrus \\
\hline $\begin{array}{l}\text { Grover et al. }{ }^{56} \\
\text { (2009) }\end{array}$ & $\begin{array}{l}20-40 \\
41-60 \\
61 \&>\end{array}$ & $273.8 \pm 23$ & $266 \pm 21.9$ & 50 & Central $1 \mathrm{~mm}$ & $273 \pm 20.8$ & $256.5 \pm 16.9$ & Spectralis \\
\hline $\begin{array}{l}\text { Kelty et al. }{ }^{57} \\
(2008)\end{array}$ & $36.8 \pm 12.1$ & $\begin{array}{l}220 \pm 26 \\
281 \pm 15 \\
294 \pm 14 \\
296 \pm 15 \\
293 \pm 15 \\
236 \pm 16 \\
255 \pm 16 \\
273 \pm 15 \\
247 \pm 16\end{array}$ & $\begin{array}{l}199 \pm 26 \\
267 \pm 23 \\
281 \pm 22 \\
279 \pm 23 \\
281 \pm 20 \\
227 \pm 20 \\
248 \pm 20 \\
268 \pm 22 \\
242 \pm 31\end{array}$ & 83 & $\begin{array}{l}\text { Central } 1 \mathrm{~mm} \\
\text { Temporal inner macula } \\
\text { Superior inner macula } \\
\text { Nasal inner macula } \\
\text { Inferior inner macula } \\
\text { Temporal outer macula } \\
\text { Superior outer macula } \\
\text { Nasal outer macula } \\
\text { Inferior outer macula }\end{array}$ & $\begin{array}{l}219 \pm 25 \\
275 \pm 23 \\
290 \pm 20 \\
290 \pm 23 \\
290 \pm 19 \\
233 \pm 20 \\
252 \pm 19 \\
272 \pm 20 \\
245 \pm 31\end{array}$ & $\begin{array}{l}186 \pm 17 \\
267 \pm 18 \\
278 \pm 19 \\
277 \pm 18 \\
281 \pm 18 \\
227 \pm 17 \\
248 \pm 18 \\
266 \pm 19 \\
242 \pm 17\end{array}$ & Stratus \\
\hline $\begin{array}{l}\text { Asefzadeh et al. }{ }^{58} \\
\text { (2007) }\end{array}$ & $69 \pm 5$ & $\begin{array}{l}N R \\
N R \\
N R\end{array}$ & $\begin{array}{l}189 \pm 20 \\
N R \\
N R\end{array}$ & 14 & $\begin{array}{l}\text { Central subfield } \\
\text { Total foveal } \\
\text { Total macular }\end{array}$ & $\begin{array}{l}184 \pm 29 \\
228 \pm 17 \\
248 \pm 14\end{array}$ & $\begin{array}{l}160 \pm 26 \\
204 \pm 17 \\
232 \pm 13\end{array}$ & Stratus \\
\hline
\end{tabular}

EDTRS, Early Treatment Diabetic Retinopathy Study; NR, not reported; OCT, ocular coherence tomography; SD, standard deviation.

Ageing also affects other structures such as the RPE. A tessellated or tigroid fundus is observed in ophthalmoscopy because of the loss of RPE melanin and choroidal pigmentation secondary to ageing. ${ }^{1,45}$ Drusen and cystoid degeneration seen in the peripheral retina increases with age. ${ }^{45}$

Retinal thickness generally reduces with age at all areas except the fovea. ${ }^{59}$ A significant correlation has also been found between attenuation of parafoveal retinal thickness and age. ${ }^{59}$ Kashani et al. ${ }^{54}$, however, showed that there was a significant increase in foveal thickness with age and suggested that it is important to control for variation in OCT parameters based on age. Kelty et al. ${ }^{57}$ showed that the mean macula thickness was not affected significantly by age.

\section{Gender}

Kashani et al..$^{54}$ reported thicker retina in males compared with those of their female counterparts. The authors concluded that the significant preponderance of women with macula holes in the population may be related to their relatively thinner retinas. A study by Wong et al. ${ }^{61}$ using Stratus OCT showed that gender was significantly associated with central retinal thickness $(p<0.05)$. Other studies ${ }^{34,57}$ have also found that mean foveal thicknesses were significantly thicker in 
males than in females $(p<0.001)$. Interestingly, a study in which spectral domain (SD) OCT was used found no sexrelated difference in central macular thickness. ${ }^{53}$ Also, Budenz et al..$^{32}$ found no statistically significant relationships between gender and NFL thickness $(p=0.34)$.

\section{Race and ethnicity}

Poinoosawmy et al. ${ }^{41}$, using laser scanning polarimetry, found that on average, Caucasians had significantly thicker NFL than Afro-Caribbean subjects. The thinner NFL in the AfroCaribbean Americans may contribute to the higher prevalence of glaucoma and glaucomatous damage in this population. However, OCT analysis of NFL thickness has shown that African Americans had thicker NFL thickness than that of Caucasians, both superiorly and inferiorly. ${ }^{38}$ These racial differences may be attributed to differences in optic disc size because a larger disc is postulated to contain more nerve fibres. Budenz et al. ${ }^{32}$ studied mean NFL thickness in different ethnic groups. Comparisons between ethnic groups revealed that Caucasians had mean NFL values $(98.1 \mu \mathrm{m} \pm 10.9 \mu \mathrm{m})$ slightly thinner than those of Hispanics $(103 \mu \mathrm{m} \pm 11.6 \mu \mathrm{m})$ $(p=0.001)$ or Asians $(105.8 \mu \mathrm{m} \pm 9.2 \mu \mathrm{m} ; p=0.031)$. Knight et al. ${ }^{16}$ determined the effect of race on optic nerve head and retinal NFL thickness measurements using SD-OCT. Those of European descent had thinner NFL measurements in the temporal quadrant. A South African study. ${ }^{13}$ reported that mean global NFL thicknesses were slightly greater in black South Africans than Indian South Africans. The results of the above-mentioned studies demonstrated that there are differences in optic nerve and retinal topography across racial groups and these differences should be considered when assessing glaucomatous damage and other optic nerve head pathologies in different racial populations.

Asefzadeh et al. ${ }^{58}$ used time-domain OCT and observed that African Americans had significantly thinner total foveal and macula thicknesses compared with age-matched Caucasians in a small sample $(n=14)$. Kashani et al. ${ }^{54}$ and Kelty et al. ${ }^{57}$ replicated the same study using a larger sample size and found that the mean foveal thicknesses in African Americans were significantly thinner than in Caucasians. WagnerSchuman et al..$^{50}$, using SD-OCT, reported that Africans and African Americans had a significant reduction in central retinal thickness compared with Caucasians.

Tariq et $a .^{62}$ found that Caucasian children had thicker macula parameters compared with Asian children. The largest differences existed in the central macula and these differences have important implications for detecting and diagnosing retinal diseases. El-Dairi et al. ${ }^{28}$ found that black children had smaller foveal thickness compared with white children. Huynh et al. ${ }^{34}$ evaluated differences in retinal thickness between Caucasians and East Asians children aged 6 years and found thicker minimum foveal, central macula and average inner macula thicknesses in Caucasian children. Racial differences should therefore be considered when interpreting OCT scans.

\section{Axial length}

Several studies have reported relationships between axial length and NFL. Huynh et al..$^{34}$ reported that the average NFL thickness decreases by $2.2 \mu \mathrm{m}$ for every 1-mm increase in axial length. El-Dairi et al. ${ }^{28}$ reported a similar relationship between NFL thickness and axial length measurements in Caucasian children. Budenz et al. ${ }^{32}$ reported that the longer the eye, the thinner the mean NFL $(p<0.001)$ and for every 1-mm-greater axial length, NFL thickness was thinner by approximately $2.2 \mu \mathrm{m}$ (95\% CI, 1.1-3.4). Leung et al. ${ }^{36}$ also found a strong positive correlation between axial length and temporal NFL thickness in Chinese subjects. Murugan et al. ${ }^{13}$ reported that NFL thickness decreased in all quadrants with increasing axial lengths in black and Indian students of the University of KwaZulu-Natal, South Africa. This inverse relationship between NFL thickness and axial length could be because of the stretching and subsequent thinning of the retina in myopia resulting in the reduction of the NFL. ${ }^{36}$ Tariq et al. ${ }^{63}$ also suggested that thinner NFL measurements in eyes with longer axial lengths could be because the area over which the retinal ganglion cells are spread is larger.

Gobel et al. ${ }^{64}$ found that macula thickness was not dependent upon length of the eye, and that no corrections were necessary when analysing pathological retinal thickening, such as in diabetic retinal disease. Wakitani et al. ${ }^{65}$ and Tewari et al. ${ }^{66}$ found no correlation between macula thickness and axial length of the eye.

\section{Refractive error}

NFL thickness has been reported to be affected by the refractive status. Budenz et al. ${ }^{32}$ found that myopic eyes had significantly thinner NFL thickness $(p=0.019)$, with mean NFL thickness decreasing by approximately $0.9 \mu \mathrm{m}$ for every 1-D change in spherical equivalent power towards greater myopia (95\% CI, 0.2-1.6). Liu et al. ${ }^{67}$ found that subjects with high corneal astigmatism had thinner NFL thickness in the temporal quadrant and a larger disc and rim areas. The authors concluded that the degree of corneal astigmatism should be considered when interpreting NFL thickness and the optic nerve head parameters when using the Cirrus HDOCT in high myopes. Other reports. ${ }^{13,63}$ have also shown significant correlations between NFL thickness and myopic spherical equivalent. However, Hoh et al. ${ }^{68}$ found no relationship between NFL thickness and refractive error in 132 young Asian male military subjects. A substantial proportion of non-glaucomatous myopic eyes have thinner NFL and ganglion cell complex. ${ }^{69,70}$

A previous report. ${ }^{71}$ has hypothesised that highly myopic eyes would have thinner retinas than emmetropic eyes. Huynh et al. ${ }^{72}$ found that increasing myopia was associated with reduced macula thickness. However, Kelty et al. ${ }^{57}$ and Wakitani et al. ${ }^{65}$ found no correlation between macula thickness and the refractive error. Similarly, Tewari et al. ${ }^{66}$ found no significant correlation between refraction and minimum and average foveal thicknesses. The reasons for these differences in research findings are yet to be determined. 


\section{Conclusion}

Given the important role that retinal parameters play in the diagnosis and management of various ocular diseases, and the susceptibility of these parameters to retinal diseases, it is worthwhile to review its general anatomy and factors that may influence them. However, limitations of the studies cited in this review include the use of different types of instruments and inconsistencies with ages, gender, sample sizes, ethnic diversity as well as different statistical methods used in the data analysis.

\section{Acknowledgements}

This work is part of the PhD vision science project funded by the Medical Research Council, South Africa.

\section{Competing interests}

The authors declare that they have no financial or personal relationships which may have inappropriately influenced them in writing this article.

\section{Authors' contributions}

Both K.P.M. and O.A.O. contributed equally in the writing of this article.

\section{References}

1. Kanski JJ. Clinical ophthalmology: A systemic approach. London: Butterworth Heinemann; 2007.

2. Ishikawa H, Stein DM, Wollstein G, Beaton S, Fujimoto JG, Schuman JS. Macula segmentation with optical coherence tomography. Invest Ophthalmol Vis Sci. 2005;46:2012-2017.

3. Riordan-Eva P, Whitcher JP. Vaughan \& Asbury's general ophthalmology. 16th ed. Boston, MA: McGraw Hill; 2004

4. Alexander LJ. Diseases of the optic nerve. In: Bartlett JD, Jaanus SD, editors. Clinical ocular pharmacology. 2nd ed. Boston, MA: Butterworth, 1989; pp. 455-489.

5. Shepherd G. The synaptic organization of the brain. New York: Oxford University Press; 2004

6. Lalezary M, Medeiros FA, Weinreb RN, et al. Baseline optical coherence tomography predicts the development of glaucomatous change in glaucoma suspects. Am J Ophthalmol. 2006;142:576-582.

7. Hee MR, Puliafito CA, Duker JS, et al. Topography of diabetic macular edema with optical coherence tomography. Ophthalmology. 1998;105:360-370.

8. Parisi V. Correlation between morphological and functional retinal impairment in patients affected by ocular hypertension, glaucoma, demyelinating optic neuritis and Alzheimer's disease. Semin Ophthalmol. 2003;18:50-57.

9. Chow CC, Shah RJ, Lim JI, Chau FY, Hallak JA, Vajaranant TS. Peripapillary retina nerve fiber layer thickness in sickle-cell hemoglobinopathies using spectraldomain optical coherence tomography. Am J Ophthalmol. 2013;155:456-464.

10. Blanks JC, Schmidt SY, Torigoe Y, Porrello KV, Hinton DR, Blanks RH. Retina pathology in Alzheimer's disease. II. Regional neuron loss and glial changes in GCL. Neurobiol Ageing. 1996;17:385-395.

11. Fanihagh F, Kremmer S, Anastassiou C, Schallenberg M. Optical coherence tomography, scanning laser polarimetry and confocal scanning laser ophthalmoscopy in retinal nerve fiber layer measurements of glaucoma patients. Open Ophthalmol J. 2015;9:41-48.

12. Townsend KA, Wollstein G, Schuman JS. Imaging of the retinal nerve fiber layer for glaucoma. Br J Ophthalmol. 2009;93:139-143.

13. Murugan C, Golodza BZ, Pillay K, et al. Retinal nerve fibre layer thickness of black and Indian myopic students at the University of KwaZulu-Natal. Afr Vision Eye Health. 2015;74(1), Art. \#24, 6 pages. http://dx.doi.org/10.4102/aveh.v74i1.24

14. Pawar N, Maheshwari D, Ravindran M, Ramakrishnan R. Retinal nerve fiber layer thickness in normal Indian pediatric population measured with optical coherence tomography. Indian J Ophthalmol. 2015;62:412-418.

15. Turk A, Ceylan OM, Arici C, et al. Evaluation of the nerve fiber layer and macula in the eyes of healthy children using spectral-domain optical coherence tomography. Am J Ophthalmol. 2012;153:552-559.
16. Knight OJ, Girkin CA, Budenz DL, Durbin MK, Feuer WJ. Effect of race, age and axial length on optic nerve head parameters and retinal nerve fiber layer thickness measured by Cirrus HD-OCT. Arch Ophthalmol. 2012;130:312-318.

17. Pinilla I, Garcia-Martin E, Idoipe M, Sancho E, Fuertes I. Comparison of retinal nerve fiber layer thickness measurements in healthy subjects using Fourier and time domain optical coherence tomography. J Ophthalmol. 2012;2012:107053, 6 pages. http://dx.doi.org/10.1155/2012/107053

18. Hlozanek M, Osmera J, Lezatkova P, Sedlackova P, Filous A. The retinal nerve fibre layer thickness in glaucomatous hydrophthalmic eyes assessed by scanning laser polarimetry with variable corneal compensation in comparison with age-matched healthy children. Acta Ophthalmol. 2012;90:709-712.

19. Larsson E, Eriksson U, Alm A. Retinal nerve fibre layer thickness in full-term children assessed with Heidelberg retinal tomography and optical coherence tomography: Normal values and interocular asymmetry. Acta Ophthalmol. 2011;89:151-158.

20. Girkin CA, McGwin G, Sinai MJ, et al. Variation in optic nerve and macular structure with age and race with spectral-domain optical coherence tomography. Ophthalmology. 2011;118:2403-2408.

21. Rolle T, Briamonte C, Curto D, Grignolo FM. Ganglion cell complex and retina nerve fiber layer measured by Fourier-domain optical coherence tomography for early detection of structural damage in patients with preperimetric glaucoma. Clin Ophthalmol. 2011;5:61-69.

22. Mwanza JC, Durbin MK, Budenz DL, Cirrus OCT Normative Database Study Group Interocular symmetry in peripapillary retinal nerve fiber layer thickness measured with the Cirrus HD-OCT in healthy eyes. Am J Ophthalmol. 2011;151:514-521.

23. Leung MM, Huang RY, Lam AK. Retinal nerve fiber layer thickness in normal Hong Kong Chinese children measured with optical coherence tomography. J Glaucoma. 2010;19:95-99.

24. Kanno $M$, Nagasawa $M$, Suzuki $M$, Yamashita $H$. Peripapillary retinal nerve fiber layer thickness in normal Japanese eyes measured with optical coherence tomography. Jpn J Ophthalmol. 2010;54:36-42.

25. Kim MJ, Lee EJ, Kim TW. Peripapillary retinal nerve fibre layer thickness profile in subjects with myopia measured using the Stratus optical coherence tomography. Br J Ophthalmol. 2010;94:115-120.

26. Samarawickrama C, Wang JJ, Huynh SC, et al. Ethnic differences in optic nerve head and retinal nerve fibre layer thickness parameters in children. Br J Ophthalmol. 2010;94(7):871-876. http://dx.doi.org/10.1136/bjo.2009.158279

27. Hirasawa $H$, Tomidokoro $A$, Araie $M$, et al. Peripapillary retinal nerve fiber layer thickness determined by spectral-domain optical coherence tomography in ophthalmologically normal eyes. Arch Ophthalmol. 2010;128:1420-1426.

28. El-Dairi MA, Asrani SG, Enyedi LB, Freedman SF. Optical coherence tomography in the eyes of normal children. Arch Ophthalmol. 2009;127:50-58.

29. Lu AT, Wang M, Varma R, et al. Combining nerve fiber layer parameters to optimize glaucoma diagnosis with optical coherence tomography. Ophthalmology. 2008;115:1352-1357.

30. Gupta G, Donahue JP, You T. Profile of the retina by optical coherence tomography in the pediatric age group. Am J Ophthalmol. 2007;144:309-310.

31. Parikh RS, Parikh SR, Sekhar GC, Prabakaran S, Babu JG, Thomas R. Normal age-related decay of retinal nerve fiber layer thickness. Ophthalmology. 2007;114:921-926.

32. Budenz DL, Anderson DR, Varma R, et al. Determinants of normal retinal nerve fiber layer thickness measured by Stratus OCT. Ophthalmology. 2007;114:1046-1052.

33. Salchow DJ, Oleynikov YS, Chang MF, et al. Retinal nerve fiber layer thickness in normal children measured with optical coherence tomography. Ophthalmology. 2006;113:768-791.

34. Huynh SC, Wang XY, Rochtchima E, Mitchell P. Peripapillary retinal nerve fibre layer thickness in a population of 6-year-old children: Findings by optical coherence tomography. Ophthalmology. 2006;113:1583-1592.

35. Repka MX, Goldenberg-Cohen N, Edwards AR. Retinal nerve fiber layer thickness in amblyopic eyes. Am J Ophthalmol. 2006;142:247-251.

36. Leung CKS, Mohamed S, Leung KS, et al. Retinal nerve fiber layer measurements in myopia: An optical coherence tomography study. Invest Ophthalmol Vis Sci. 2006;47:5171-5176.

37. Ahn HC, Son HW, Kim JS, Lee JH. Quantitative analysis of retinal nerve fiber laye thickness of normal children and adolescents. Korean J Ophthalmol. 2005;19: 195-200.

38. Racette $L$, Boden C, Kleinhandler SL, et al. Differences in visual function and optic nerve structure between healthy eyes of blacks and whites. Arch Ophthalmol. 2005;123:1547-1553.

39. Mrugacz M, Bakunowicz-Lazarczyk A. Optical coherence tomography measurement of the retinal nerve fiber layer in normal and juvenile glaucomatous eyes. Ophthalmologica. 2005;219:80-85.

40. Bowd C, Zangwill LM, Blumenthal EZ, et al. Imaging of the optic disc and retina nerve fiber layer: The effects of age, optic disc area, refractive error, and gender. Opt Soc Am A Opt Image Sci Vis. 2002;19:197-207.

41. Poinoosawmy D, Fontana L, Wu JX, Fitzke F, Hitchings R. Variation of nerve fiber layer thickness measurements with age and ethnicity by scanning lase polarimetry. Br J Ophthalmol. 1997;81:350-354.

42. Cohen Al. The retina. In: Hart MJ Jr, editor. Adler's physiology of the eye. 9th ed. St Louis, MO: Mosby, 1992; pp. 579-695.

43. Kass MA, Heuer DK, Higginbotham EJ, et al. The ocular hypertension treatment study: A randomized trial determines that topical ocular hypotensive medication delays or prevents the onset of primary open-angle glaucoma. Arch Ophthalmol. 2002;120:701-713. 
44. Linberg KA, Fisher SK. Ultrastructure of the interplexiform cell of the human retina. Invest Ophthalmol Vis Sci. 1983;24(Suppl):259.

45. Park SS, Sigelman J, Gragoudas ES. The anatomy and cell biology of the retina. In: Tasman W, Jaeger EA, editors. Duane's foundations of clinical ophthalmology. Volume 1. Philadelphia, PA: Lippincott, 1994; pp. 21-50.

46. Sharma RK, Ehinger BEJ. Development and structure of the retina. In: Kaufman PL, Alm A, editors. Adler's physiology of the eye. 10th ed. St Louis, MO, 2003, pp. 319-347.

47. Picaud S. Retinal biochemistry. In: Kaufman PL, Alm A, editors. Adler's physiology of the eye. St Louis, MO: Mosby, 2003; pp. 382-408.

48. Tan O, Li G, Lu AT, Varma R, Huang D. Mapping of macular substructures with optical coherence tomography for glaucoma diagnosis. Ophthalmology. 2008;115:949-956.

49. Hood DC, Raza AS, de Moraes CGV, Liebman JM, Ritch R. Glaucomatous damage of the macula. Prog Retin Eye Res. 2013;32C:1-21.

50. Wagner-Schuman M, Dubis AM, Nordgren RN, et al. Race- and sex-related differences in retinal thickness and foveal pit morphology. Invest Ophthalmol Vis Sci. 2011;52:625-634.

51. Liu T, Hu A, Kaines A, Yu FEI, Schwartz SD, Hubschman JP. A pilot study of normative data for macular thickness and volume measurements using Cirrus high-definition optical coherence tomography. Retina. 2011;31:1944-1950.

52. Wexler A, Sand T, Elsas TB. Macular thickness measurements in healthy Norwegians volunteers: An optical coherence tomography study. BMC Ophthalmol. 2010;10:13. http://dx.doi.org/10.1186/1471-2415-10-13

53. Sull AC, Vuong LN, Price LL, et al. Comparison of Spectral/Fourier domain optical coherence tomography instruments for assessment of normal macular thickness. Retina. 2010;30:235-245.

54. Kashani AH, Zimmer-Galler IE, Shah SM, et al. Retinal thickness analysis by race, gender, and age using Stratus OCT'" Am J Ophthalmol. 2010;149:496-502.

55. Song WK, Lee SC, Lee ES, Kim CY, Kim SS. Macular thickness variations with sex, age, and axial length in healthy subjects: A spectral domain-optical coherence tomography study. Invest Ophthalmol Vis Sci. 2010;51:3913-3918.

56. Grover S, Murthy RK, Brar VS, Chalam KV. Normative data for macular thickness by high-definition spectral-domain optical coherence tomography (Spectralis). Am J Ophthalmol. 2009;148:266-271.

57. Kelty PJ, Payne JF, Trivedi RH, Kelty J, Bowie EM, Burger BM. Macular thickness assessment in healthy eyes based on ethnicity using Stratus OCT optical coherence tomography. Invest Ophthalmol Vis Sci. 2008;49:2668-2672.

58. Asefzadeh B, Cavallerano AA, Fisch BM. Racial differences in macular thickness in healthy eyes. Optom Vis Sci. 2007;84:941-945.
59. Kanai K, Abe T, Murayama K, Yoneya S. Retinal thickness and changes with age. Nippon Ganka Gakkai Zasshi. 2002;106:162-165.

60. Quigley HA, Dunkelberger GR, Green WR. Retinal ganglion cell atrophy correlated with automated perimetry in human eyes with glaucoma. Am J Ophthalmol. 1989;107:453-464.

61. Wong AC, Chan CW, Hui SP. Relationship of gender, body mass index, and axial length with central retinal thickness using optical coherence tomography. Eye. 2005;19:292-297.

62. Tariq YM, Li H, Burlutsky G, Mitchell P. Ethnic differences in macular thickness. Clin Exp Ophthalmol. 2012;39:893-898.

63. Tariq Y, Samarawickrama C, Pai A, Burlutsky G, Mitchell P. Impact of ethnicity on the correlation of retinal parameters with axial length. Invest Ophthalmol Vis Sci. 2010;51:4977-4982.

64. Gobel W, Hartmann F, Haigis W. Determination of retinal thickness in relation to the age and axial length using optical coherence tomography. Ophthalmologe. 2001;98:157-162.

65. Wakitani $Y$, Sasoh $M$, Sugimoto $M$, Ito $Y$, Ido $M$, Uji $Y$. Macular thickness measurements in healthy subjects with different axial lengths using optical coherence tomography. Retina. 2003;23:177-182.

66. Tewari HK, Wagh VB, Sony P, Venkatesh P, Singh R. Macular thickness evaluation using the optical coherence tomography in normal Indian eyes. Ind J Ophthalmol. 2004;52:199-204.

67. Liu L, Zou J, Huang H, Yang J, Chen S. The influence of corneal astigmatism on retinal nerve fibre layer thickness and optic nerve head parameter measurements by Spectral-domain optical coherence tomography. Diag Pathol. 2012;7:55. http:// dx.doi.org/10.1186/1746-1596-7-55

68. Hoh ST, Lim MC, Seah SK, et al. Peripapillary retinal nerve fiber layer thickness variations with myopia. Ophthalmology. 2006;113:773-777.

69. Kim NR, Lim H, Kim JH, Rho SS, Seong GJ, Kim CY. Factors associated with false positives in retinal nerve fiber color codes from spectral-domain optical coherence tomography. Ophthalmology. 2011;118:1774-1781.

70. Qiu KL, Zhang MZ, Leung CK, et al. Diagnostic classification of retinal nerve fiber layer measurement in myopic eyes: A comparison between time-domain and spectral-domain optical coherence tomography. Am J Ophthalmol. 2011;152: 646-653.

71. Karlin DB, Curtin BJ. Peripheral chorioretinal lesions and axial length of the myopic eye. Am J Ophthalmol. 1976;81:625-631.

72. Huynh SC, Wang XY, Rochtchima E, Mitchell P. Distribution of macular thickness by optical coherence tomography: Findings from a population-based study of 6-yearold children. Invest Ophthalmol Vis Sci. 2006;47:2351-2357. 